\title{
Solanum gilo: HOSPEDEIRA AECIAL DE Puccinia substriata, AGENTE CAUSAL DA FERRUGEM DO MILHETO NO BRASIL
}

\author{
MILTON L. PAZ LIMA, ZULEIDE M. CHAVES, BERNARDO UENO \& ADALBERTO C. CAFÉ FILHO
}

Universidade de Brasília, Departamento de Fitopatologia, CEP 70910-900, Brasília-DF, e-mail: fitolima@unb.br

(Aceito para publicação em 14/08/2001)

Autor para correspondência: Milton L. Paz Lima

\section{ABSTRACT}

First record of Solanum gilo as aecial host of Puccinia substriata, the agent of rust of pearl millet in Brazil

Rust of Solanum gilo is often found during the dry season in Distrito Federal, Brazil. Plants of cv. Verde Claro have been found with foliar lesions showing pycnium, aecium and heteroecium stages ( 0 and I) of Puccinia substritata, the causal agent of pearl millet (Pennisetum glaucum) rust. Dimensions of fungal structures were: aecium 240-270 x 360-420 $\mu \mathrm{m}$, ecióspores $23-25 \mu \mathrm{m}$, peridial cell $18-35 \mu \mathrm{m}$ and pycnia $120 \mathrm{x}$ $108 \mu \mathrm{m}$.
Ramakrishnan et al. (Ind.Phytopath. 1:97-103.1948) identificaram originalmente a berinjela (Solanum melongena L.) como hospedeiro aecial de Puccinia substriata Ellis \& Barthol. No Brasil, Figueiredo (Arq.Inst.Biol. 38:173175.1971) citou a presença em berinjela da forma aecial e picnial de $P$. substriata em apenas um lado da folha e da forma uredinial em Digitaria sanguinalis (L.) Scop. e Paspalum spp.

Wilson et al. (Plant Dis. 80:806-808. 1996), em inoculação artificial de écios em germoplasmas do gênero Solanum observaram em jiló (Solanum gilo Raddi) incidência de plantas suscetíveis de $6 \%$ em campo e de $71 \%$ em casa de vegetação, sendo este o primeiro registro de jiló como hospedeiro aecial de $P$. substriata.

Charchar \& Anjos (Fitopatol. Bras. 25:564. 2000) relataram $P$. substriata var. penicillariae causando danos à cultura desde 1997, com redução na qualidade da forragem e na produção de grãos.

Folhas de jiló, cv. Verde Claro, coletadas no período de seca (agosto/2000), no Distrito Federal, foram herborizadas, exsicatadas e depositadas na Coleção Micológica de Referência da Universidade de Brasília ( ${ }^{\text {o. }}$ 18.314). As folhas de jiló apresentaram estruturas de $P$. substriata (Figura 1), incluindo écio (240-270 x 360-420 $\mu \mathrm{m})$, eciósporos $(23-25 \mu \mathrm{m})$, células peridiais $(18-35 \mu \mathrm{m}) \mathrm{e}$ pícnia (120-125 x 108-115 $\mu \mathrm{m})$. Foram observadas diferenças quanto à posição dos estágios fúngicos, tais como: presença na face abaxial da fase aecial e na face adaxial a fase picnial, resultado análogo ao obtido por Figueiredo et al. (1971), em $S$. melongena. Este é o primeiro registro de $P$. substriata ocorrendo naturalmente em jiló.

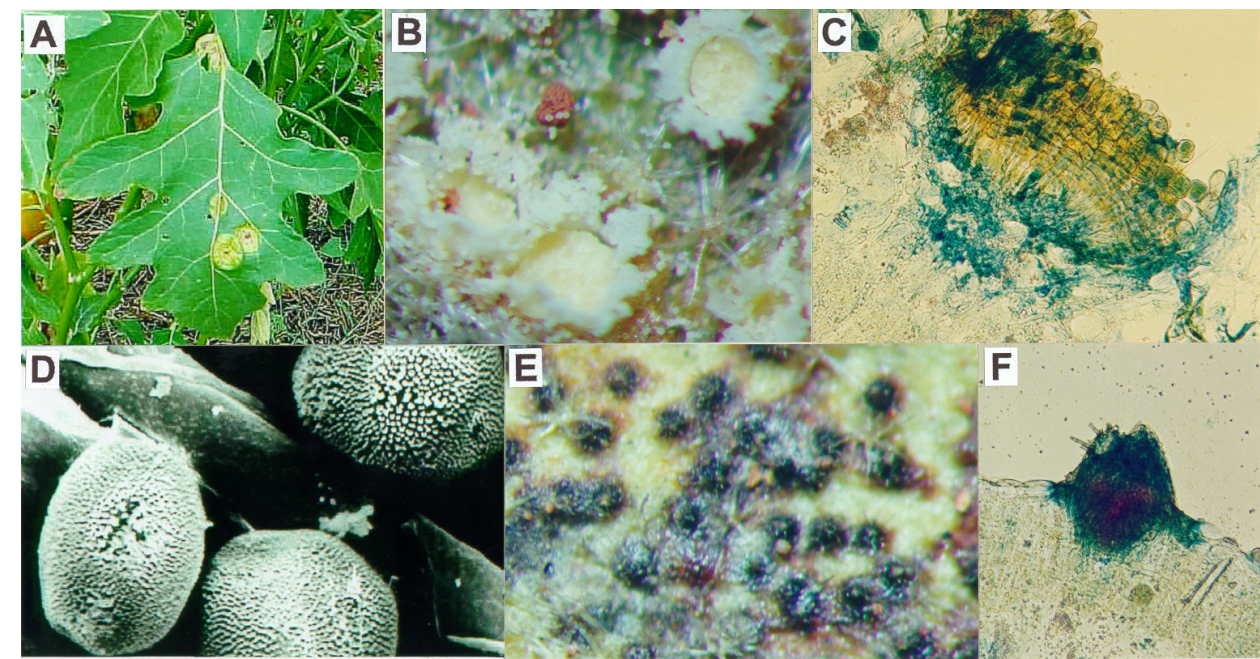

FIG. 1 - Puccinia substriata em folhas de jiló (Solanum gilo): A - sintoma; B - fase aecídica vista em microscópio estereoscópico; $\mathrm{C}$ - corte transversal do écio (I); D - eciósporo visto em MEV; E - pícnia vista em microscópio estereoscópico; $\mathrm{F}$ - corte transversal da pícnia $(0)$. 